\title{
Optimization of electrocoagulation operating parameters for COD removal from olive mill wastewater: application of Box-Behnken design
}

\author{
Fatima Erraib ${ }^{1}$ and Khalid El Ass ${ }^{2, *}$ \\ ${ }^{1}$ Research Laboratory of Applied Geophysics, Geotechnics, Engineering Geology and Environment \\ (L3GIE), Ecole Mohammadia d'Ingénieurs B.P 765 Agdal 10100 Rabat, Morocco \\ ${ }^{2}$ Environmental Metrology Laboratory (EML), Ecole Nationale Supérieure des Mines de \\ Rabat (ENSMR), BP. 753 Agdal-Rabat, Morocco
}

\begin{abstract}
Box-Behnken response surface design was successfully employed to optimize and study the olive mill wastewater (OMW) treatment by electrocoagulation (EC) process. The influence of four decisive factors were modelled and optimized to increase the removal of chemical oxygen demand (COD). The Box-Behnken design (BBD) results were analyzed and the second-order polynomial model was developed using multiple regression analysis. The model developed from the experimental design was predictive and a good fit with the experimental data with a high coefficient of determination $\left(\mathrm{R}^{2}\right)$ value (more than 0.98 ). The optimal operating conditions based on Derringer's desired function methodology are found to be; initial $\mathrm{pH}$ of 4.4 , a current density of $27.6 \mathrm{~mA} / \mathrm{cm}^{2}$, electrolysis time of $14.1 \mathrm{~min}$, and chloride concentration of $3.2 \mathrm{~g} / \mathrm{L}$. Under these conditions, the predicted COD removal efficiency was found to be $67.14 \%$ with a desirability value of 0.94 . These experimental results were confirmed by validation experiments and proved that Box-Behnken design and response surface methodology could efficiently be applied for modelling of COD removal from OMW.
\end{abstract}

Keywords: Olive mill wastewater, electrocoagulation, Box-Behnken design, response surface methodology.

\section{Introduction}

Olive oil production is one of the most traditional agricultural industries with great economic importance in most of the Mediterranean countries. The Mediterranean region alone provides $98 \%$ of the total surface for olive tree cultivation and $97 \%$ of the world total olive oil production, which has been estimated at 2.74 million tons in the last six years ${ }^{1}$. However, the extraction process generates a considerable amount of olive mill wastewater (OMW), a highly polluted effluent with the volume reaches more than 30 million $\mathrm{m}^{3}$ per year ${ }^{2}$.

The extraction of olive oil generates vast quantities of wastes that may have a high impact on land and water environments because of their high phytotoxicity. Due to their high load of organic matter, a series of hazards of these effluents related to the contamination of soil, hindrance of plants growth, leaks to the underground aquifers, pollution of water bodies, inhibition of auto purification processes, as well as phytotoxic impacts to aquatic fauna and to ecological equilibria and intense odour nuisance have been reported so far ${ }^{2-5}$.
Olive mill wastewaters (OMW) composition is highly variable and depends, in particular, by variety, ripeness and type of the oil extraction technology. The olive oil extraction systems could be classified in two main categories: traditional pressing process, used for many centuries with minor modifications, and centrifugal processes, including two centrifugation systems, called three- and two-phase systems. Generally, OMW is a foul-smelling acidic wastewater composed of water (83-92\%), organic matter $(4-16 \%)$ and minerals $(1-2 \%)^{6}$. The organic load reflected in the high biological oxygen demand (up to $100 \mathrm{~g} \mathrm{l}^{-1}$ ) and chemical oxygen demand (up to $200 \mathrm{~g}$ $1^{-1}$ ) concentrations ${ }^{7,8}$ comprises sugars, nitrogenous compounds, fatty acids, polyalcohols, polyphenols, pectin and fats ${ }^{9,10}$. Phenolic fraction characterized by its great variety and complexity is regarded as the most embarrassing part of OMW ${ }^{11,12}$. This fraction, which resists biological degradation, causes harmful effects on the flora and fauna of disposed of areas ${ }^{4}$.

OMW also exhibit significant saline toxicity levels, confirmed by high electroconductivity (EC) values. Inorganic compounds including chloride, sulphate 
and phosphoric salts of potassium, calcium, iron, magnesium, sodium and traces of other elements ${ }^{13}$.

The difficulty in treating OMW resides in its high content in recalcitrant organic compounds, most of which are resistant to conventional processes ${ }^{12}$.

Nowadays, the most common method for eliminating OMW is through evaporation in storage ponds, owing to the low investment required and the climate conditions in Mediterranean countries ${ }^{14}$. However, this operating method has several important disadvantages, such as bad odour, infiltration and insect proliferation ${ }^{15}$.

Several physicochemical, biological and combined processes have been examined for the treatment of OMW, resulting in considerable organic load and toxicity abatement, such as biological processes, aerobic and anaerobic 16-18, advanced oxidation processes, owing to the strong oxidation potential of the agents used ${ }^{8}$, chemical precipitation using lime ${ }^{19}$, adsorption using different mineral substrates as adsorbents ${ }^{20-22}$, nanofiltration and reverse osmosis membranes $5,23,24$. However, these processes suffer from serious inconveniences such as high cost, low efficiency and sludge disposal problems.

In recent years there has been growing interest in electro-chemical oxidation processes for the treatment of industrial effluents and therefore for the treatment of olive mill wastewater as well. Gotsi et al. ${ }^{25}$ applied electrochemical oxidation of OMW with a titaniumtantalum-platinum-iridium anode. Almost complete degradation of phenols was achieved, but relatively low COD removal $(40 \%)$ even after long operation times. Subsequently, Tezcan Ün et al. ${ }^{26}$ investigated the electrochemical oxidation of three-phase technology OMW using $\mathrm{Ti} / \mathrm{RuO} 2$ anode. The treated OMW effluent presented a final COD around 167 $\mathrm{mg} / \mathrm{L} \quad(99.6 \%$ removal efficiency) and almost complete abatement of phenolic compounds. Recently, Flores et al. ${ }^{27}$ reported the treatment of OMW by electrochemical oxidation with a BDD anode and an air-diffusion cathode for the generation of $\mathrm{H}_{2} \mathrm{O}_{2}$, electro-Fenton and photo electro-Fenton, and the latter one yielded a maximum efficiency of up to $80 \%$ mineralization.

The electrocoagulation (EC) process is one of the most useful electrochemical processes. This technique has been the subject of several studies over the last decade and remains a very active field of research ${ }^{28-30}$; unfortunately, relatively few studies report the use of this technology to treat the OMW. Inan et al. ${ }^{31}$ applied electrocoagulation for the treatment of OMW. For this purpose, aluminum and iron were used in the reactor simultaneously as materials for the electrodes. Similarly, Hanafi et al. ${ }^{32}$ examined a coupled treatment process for OMW comprising electrocoagulation using an aluminum electrode and then a biological process. Other than these studies, OMW electrocoagulation was found capable of reducing the phenolic compounds as well as oil-grease and turbidity ${ }^{33,34}$.

To date, most of the studies on the optimization of wastewater treatment process have focused on the traditional one-factor-at-a time approach. However, this approach, which does not take into account the cross effects from the factors considered, is timeconsuming and has in poor optimization results. Response surface methodology (RSM) is an efficient way to achieve such an optimization by analyzing and modelling the effects of multiple variables and their responses and finally optimizing the process 35,36 . RSM also generates a mathematical model that can be used to predict the response of a system to any new condition.

Although this method has been used for the optimization of various processes conditions that provide enhanced treatment of different wastewaters 5,36-38, it has not been well exploited to optimize COD removal in OMW by electrocoagulation.

In this study, the objective of the present study was to assess the electrocoagulation treatment of OMW. Box-Behnken statistical experiment design (BBD) and response surface methodology (RSM) were used to statistically develop model and to study and evaluate main effects, interaction effects and quadratic effects of the process parameters (initial $\mathrm{pH}$, current density, electrolysis time and $\mathrm{NaCl}$ concentration) on Chemical oxygen demand (COD) removal efficiency.

\section{Materials and methods}

\subsection{OMW characterization}

OMW was obtained from an olive oil continuous processing plant located

Fresh olive mill wastewater (OMW) used in this study was obtained from the homogenization tank of an olive oil semi-modern press plant located in BeniMellal (Morocco). OMW was collected in a closed plastic container and stored at $4^{\circ} \mathrm{C}$. The main characteristics of OMW were analyzed as per the procedures of Standard Methods 39, and average values are given in Table 1.

\subsection{Experimental procedure}

Electrocoagulation (EC) combines the functions and advantages of conventional coagulation, flotation and electrochemistry in water and wastewater treatment $30,40,41$. Upon the application of direct current, the coagulant is generated in situ by electrolytic oxidation of an appropriate anode material that leads, at appropriate $\mathrm{pH}$, to firstly destabilize small colloidal particles, and secondly, to fulfil simultaneous coagulation and flotation with less production of sludge ${ }^{42,43}$. 
Table 1. Characterization of olive mill wastewater.

\begin{tabular}{|l|l|r|}
\hline Parameter & Unit & \multicolumn{1}{|c|}{$\begin{array}{c}\text { Value } \\
\text { (mean } \pm \text { SD) }\end{array}$} \\
\hline pH & & $4.90 \pm 0.30$ \\
Conductivity & $\mathrm{mS} / \mathrm{cm}$ & $18.50 \pm 1.12$ \\
Chemical oxygen demand (COD) & $\mathrm{g} / \mathrm{L}$ & $98.21 \pm 6.70$ \\
Biological oxygen demand (BOD) & $\mathrm{g} / \mathrm{L}$ & $37.40 \pm 3.30$ \\
Total suspended solids (TSS) & g/L & $5.76 \pm 0.52$ \\
Total polyphenols & g/L & $6.80 \pm 0.73$ \\
Total Kjeldhl nitrogen (TKN) & g/L & $1.63 \pm 0.05$ \\
\hline
\end{tabular}

The proposed mechanism of chemical reactions occurring in the EC process is shown by the following main reactions at the aluminium electrodes ${ }^{29,30}$ :

$$
\begin{array}{lrl}
\text { Anode : } & \mathrm{Al}_{(\mathrm{s})} \leftrightarrow \mathrm{Al}^{3+}{ }_{(\mathrm{aq})}+3 \mathrm{e}^{-} \\
\text {Cathode : } & 3 \mathrm{H}_{2} \mathrm{O}_{(\mathrm{aq})}+3 \mathrm{e}^{-} \leftrightarrow 3 / 2 \mathrm{H}_{2(\mathrm{~g})}+3 \mathrm{OH}^{-}{ }_{(\mathrm{aq})}
\end{array}
$$

The hydroxyl ions produced at the cathode increase the $\mathrm{pH}$ in the electrolyte and we have a reaction in the aqueous solution between $\mathrm{Al}^{3+}$ and $\mathrm{OH}^{-}$ions to form aluminium hydroxide.

$$
\text { In bulk : } \quad \mathrm{Al}_{(\mathrm{aq})}^{3+}+3 \mathrm{OH}_{(\mathrm{aq})}^{-} \leftrightarrow \mathrm{Al}(\mathrm{OH})_{3(\mathrm{~s})}
$$

The generated $\mathrm{Al}^{3+}$ ions would immediately undergo further spontaneous reactions to produce corresponding hydroxides and/or poly-hydroxides in a wide $\mathrm{pH}$ range. These hydroxides/polyhydroxides/poly-hydroxy metallic compounds such as $\quad \mathrm{Al}_{6}(\mathrm{OH})_{15^{3+}}, \quad \mathrm{Al}_{7}(\mathrm{OH})_{17}{ }^{4+}, \quad \mathrm{Al}_{8}(\mathrm{OH})_{20}{ }^{4+}$, $\mathrm{Al}_{13} \mathrm{O}_{4}(\mathrm{OH})_{24}{ }^{7+}, \quad \mathrm{Al}_{13}(\mathrm{OH})_{34}{ }^{5+}$, which transform finally into $\mathrm{Al}(\mathrm{OH})_{3}$ according to complex precipitation kinetics, have a strong affinity with dispersed/dissolved ions as well as the counter ions to cause coagulation/adsorption ${ }^{31,44}$.

The electrocoagulation experiments were conducted in a home-made Plexiglas cell (Figure 1). Parallel rectangular aluminium sheets $(30 \mathrm{~mm} \times 80 \mathrm{~mm})$ used as electrodes were disposed vertically in the cell at a distance of $2 \mathrm{~cm}$ from each other and there was a $3 \mathrm{~cm}$ distance between the electrodes and the bottom of the cell which allowed easy stirring. The polarity of current was reversed at regular intervals in order to minimize the deposition on electrodes. In each run, $0.25 \mathrm{~L}$ of wastewater was placed into the reactor, and all the runs were performed for a constant temperature $\left(19-20^{\circ} \mathrm{C}\right)$. The range of current density variations was $10-30 \mathrm{~mA} / \mathrm{cm}^{2}, \mathrm{pH}$ values were taken as 4,5 , and 6 units, and duration of coagulation process varied in the limits of 10-20 min.

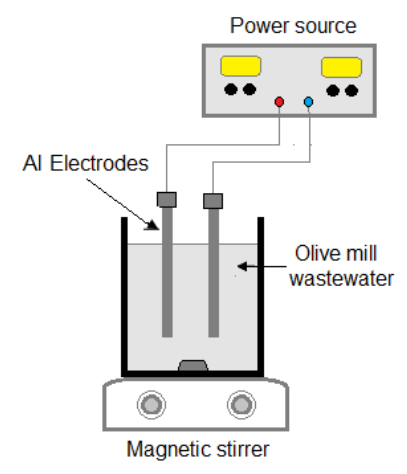

Figure 1. Schematic of the electrocoagulation cell

The treated effluents were collected, filtered and used for the determination of the COD. All experiments were performed in triplicate, and the average values were recorded. The removal efficiency ( $R$ in $\%)$ was calculated using the following equation:

$R(\%)=\frac{Y_{0}-Y}{Y} \times 100$

where $Y_{0}$ and $Y$ represent the initial and final value of COD.

\subsection{Experimental design}

Response surface methodology (RSM) is a useful statistical tool for the optimization of different processes and widely used for experimental design. In this study, Box-Behnken statistical screening design was used to statistically develop a model and to study and evaluate main effects, interaction effects and quadratic effects of the process parameters on the removal efficiency of COD. The effects of the four independent variables (initial $\mathrm{pH}\left(\mathrm{X}_{1}\right)$, current density $\left(\mathrm{X}_{2}\right)$, electrolysis time $\left(\mathrm{X}_{3}\right)$ and chloride concentration $\left(\mathrm{X}_{4}\right)$ ) on the response (COD removal) were investigated to determine the effective electrocoagulation operating conditions, which was validated by conducting additional experiments. 
Table 2. Coded and actual values of the variables of the design of experiments for the overall electrocoagulation optimization.

\begin{tabular}{|l|l|c|c|c|}
\hline Factor & Variables & \multicolumn{3}{|c|}{ Coded levels of variables } \\
\cline { 3 - 4 } & & $\mathbf{- 1}$ & $\mathbf{0}$ & $\mathbf{+ 1}$ \\
\hline $\mathbf{X}_{\mathbf{1}}$ & $\mathrm{pH}$ & 4 & 5 & 6 \\
$\mathbf{X}_{\mathbf{2}}$ & Current density $\left(\mathrm{mA} \mathrm{cm}^{-2}\right)$ & 10 & 20 & 30 \\
$\mathbf{X}_{\mathbf{3}}$ & Electrolysis time $(\mathrm{min})$ & 10 & 15 & 20 \\
$\mathbf{X}_{\mathbf{4}}$ & NaCl concentration $\left(\mathrm{g} \mathrm{l}^{-1}\right)$ & 1 & 3 & 5 \\
\hline
\end{tabular}

Table 3. Experimental design matrix and response based on the experimental runs and predicted values on COD removal (\%) proposed by BBD design.

\begin{tabular}{|c|c|c|c|c|c|c|}
\hline \multirow{2}{*}{ Run } & \multicolumn{4}{|c|}{ Independent variables } & \multicolumn{2}{|c|}{ COD Removal (\%) } \\
\hline & $\begin{array}{l}\mathrm{X}_{1} \\
\mathrm{pH}\end{array}$ & $\begin{array}{c}\mathrm{X}_{2} \\
\text { Current density } \\
\left(\mathrm{mA} / \mathrm{cm}^{2}\right)\end{array}$ & \begin{tabular}{c}
\multicolumn{1}{c}{$\mathrm{X}_{3}$} \\
Electrolysis \\
time (min)
\end{tabular} & $\begin{array}{c}\mathrm{X}_{4} \\
{[\mathrm{NaCl}]} \\
(\mathrm{g} / \mathrm{L})\end{array}$ & Experimental & Predicted \\
\hline 1 & $5(0)$ & $30(1)$ & $20(1)$ & $3(0)$ & 67,12 & 67,26 \\
\hline 2 & $5(0)$ & $20(0)$ & $15(0)$ & $3(0)$ & 62,75 & 62,75 \\
\hline 3 & $4(-1)$ & $20(0)$ & $15(0)$ & $1(-1)$ & 60,33 & 59,81 \\
\hline 4 & $5(0)$ & $20(0)$ & $10(-1)$ & $5(1)$ & 56,15 & 56,43 \\
\hline 5 & $5(0)$ & $10(-1)$ & $10(-1)$ & $3(0)$ & 56,63 & 56,77 \\
\hline 6 & $5(0)$ & $20(0)$ & $20(1)$ & $5(1)$ & 58,05 & 57,38 \\
\hline 7 & $6(0)$ & $10(-1)$ & $15(0)$ & $3(0)$ & 49,14 & 48,14 \\
\hline 8 & $4(-1)$ & $20(0)$ & $15(0)$ & $5(1)$ & 60,8 & 60,28 \\
\hline 9 & $5(0)$ & $20(0)$ & $10(-1)$ & $1(-1)$ & 54,87 & 55,65 \\
\hline 10 & $5(0)$ & $20(0)$ & $15(0)$ & $3(0)$ & 62,75 & 62,75 \\
\hline 11 & $5(0)$ & $20(0)$ & $20(1)$ & $1(-1)$ & 59,21 & 59,05 \\
\hline 12 & $5(0)$ & $30(1)$ & $15(0)$ & $5(1)$ & 63,07 & 63,11 \\
\hline 13 & $6(1)$ & $20(0)$ & $15(0)$ & $5(1)$ & 46,96 & 47,77 \\
\hline 14 & $6(1)$ & $20(0)$ & $10(-1)$ & $3(0)$ & 49,35 & 49,05 \\
\hline 15 & $5(0)$ & $20(0)$ & $15(0)$ & $3(0)$ & 62,75 & 62,75 \\
\hline 16 & $5(0)$ & $10(-1)$ & $15(0)$ & $1(-1)$ & 55,65 & 55,24 \\
\hline 17 & $5(0)$ & $30(1)$ & $10(-1)$ & $3(0)$ & 63,66 & 63,91 \\
\hline 18 & $5(0)$ & $10(-1)$ & $15(0)$ & $5(1)$ & 55,14 & 55,22 \\
\hline 19 & $5(0)$ & $30(1)$ & $15(0)$ & $1(-1)$ & 64,45 & 63,98 \\
\hline 20 & $4(-1)$ & $20(0)$ & $10(-1)$ & $3(0)$ & 62,49 & 61,36 \\
\hline 21 & $6(1)$ & $20(0)$ & $20(1)$ & $3(0)$ & 51,19 & 51,94 \\
\hline 22 & $4(-1)$ & $10(-1)$ & $15(0)$ & $3(0)$ & 59,48 & 60,65 \\
\hline 23 & $4(-1)$ & $30(1)$ & $15(0)$ & $3(0)$ & 66,93 & 68,04 \\
\hline 24 & $4(-1)$ & $20(0)$ & $20(1)$ & $3(0)$ & 62,9 & 62,81 \\
\hline 25 & $6(1)$ & $30(1)$ & $15(0)$ & $3(0)$ & 58,42 & 57,37 \\
\hline 26 & $6(1)$ & $20(0)$ & $15(0)$ & $1(-1)$ & 48,32 & 49,13 \\
\hline 27 & $5(0)$ & $10(-1)$ & $20(1)$ & $3(0)$ & 57,73 & 57,77 \\
\hline
\end{tabular}
variables. Each independent variable was coded at three levels between +1 and -1 (Table 2). A total number of 27 experiments, including three centre points were carried out, and the experimental conditions and corresponding results (responses) are presented in Table 3. A second-order polynomial model corresponding to the $\mathrm{BBD}$ was fitted to correlate the relationship between the independent variables and the response and also to identify the relevant model terms using statistical software (Design Expert 11). Considering all the linear terms, square terms and interaction items, the quadratic response model can be described as:

where $\mathrm{Y}$ is the response (COD removal efficiency, $\%) ; \beta_{0}, \beta_{i}(i=1,2,3,4)$ and $\beta_{i j}(i=1,2,3,4 ; j=1,2$, $3,4)$ are the model coefficients and $X_{i}$ and $X_{j}$ the coded independent variables.; and $\varepsilon$ is the error ${ }^{45}$.

The quality of the fit of the polynomial model equation was expressed by the coefficient of determination $R^{2}$ and the values of adjusted- $R^{2}$. The significance of each term in the equation is to estimate the goodness of fit in each case. The adequacy of the model was further justified through analysis of variance (ANOVA) and ANOVA tables were generated. The regression coefficients of the linear, 
quadratic and the interaction involved in the model and their effects were analyzed by the $F$-test and $P$ value.

In order to visualize the relationship between the response and experimental levels of each factor, the regression coefficients were used to make a statistical calculation to generate 3D surface plots from the fitted polynomial equation. These graphs are drawn by maintaining two factors constant (in turn at its middle level) and varying the other two factors in order to understand their primary and interactive effects on the dependent variables.

\section{Results and discussion}

3.1. Response analysis and interpretation by BoxBehnken design (BBD)

In order to study the combined effect of independent variables (initial $\mathrm{pH}$, current density, electrolysis time, and chloride concentration) on the COD removal efficiency, experiments were performed for different combinations of the parameters using statistically designed experiments and the results are shown in Table 3 , that includes the design and the experimental and predicted values. Model adequacy checking was performed on the experimental data to determine whether the approximating model would give poor or misleading results.

Table 4. The sequential model sum of squares and model summary statistics tested for response.

\begin{tabular}{|c|c|c|c|c|c|c|c|c|c|c|}
\hline \multirow[b]{2}{*}{ Source } & \multicolumn{5}{|c|}{ Sequential Model Sum of Squares } & \multicolumn{4}{|c|}{ Model Summary Statistics } & \multirow[t]{2}{*}{ Remarks } \\
\hline & $\mathbf{S S}^{(\mathrm{a})}$ & $\mathbf{D F}^{(\mathrm{b})}$ & $\mathbf{M S}^{(\mathrm{c})}$ & F-value ${ }^{(\mathrm{d})}$ & p-value ${ }^{(\mathrm{e})}$ & $\mathbf{S D}^{(\mathrm{f})}$ & $\mathbf{R}^{2}$ & Adj. $R^{2}$ & $\begin{array}{c}\text { Pred. } \\
\text { R }^{2}\end{array}$ & \\
\hline Mean & 42569,5 & 1 & 42569,5 & & & & & & & \\
\hline Linear & 189,90 & 4 & 47,47 & 5,80 & 0,0024 & 3,06 & 0,5134 & 0,4250 & 0,2366 & \\
\hline 2FI & 41,45 & 6 & 6,91 & 0,7980 & 0,5853 & 3,54 & 0,6255 & 0,3914 & $-0,2369$ & \\
\hline Quadratic & 131,79 & 4 & 32,95 & 58,79 & $<0.0001$ & 0,9211 & 0,9818 & 0,9606 & $\mathbf{0 , 8 9 7 0}$ & Suggested \\
\hline Cubic & 5,97 & 8 & 0,7464 & 3,96 & 0,0999 & 0,3489 & 0,9980 & 0,9867 & 0,7771 & Aliased \\
\hline Residual & 0,7545 & 4 & 0,1886 & & & & & & & \\
\hline Total & 42939,3 & 27 & 1590,3 & & & & & & & \\
\hline
\end{tabular}

(a) Sum of Squares.

(b) Degrees of Freedom of variance source.

(c) Mean of Squares (=SS/DF).

(d) F-value of variance source $=$ MS/MSres;

(e) Probability of error to be significant.

(f) Standard Deviation

Fitting of the data to various models (linear, interactive, quadratic and cubic models) was carried out to obtain the regression equation. In general, exploration of a fitted response surface may produce poor or misleading results, unless the model exhibits a good fit, which makes checking of the model adequacy essential ${ }^{46}$. To decide about the adequacy of model among various models, two different tests namely the sequential model sum of squares and model summary statistics were carried out in the present study, and the results are given in Table 4.

A quadratic model was found to be the most suitable model for COD removal. The model was found to have maximum $\mathrm{R}^{2}$, adjusted $\mathrm{R}^{2}$, predicted $\mathrm{R}^{2}$ and also exhibited low $\mathrm{p}$-values ( $\mathrm{p}$-value $<0.0001$ ). Predicted $\mathrm{R}^{2}$ is a measure of how good the model predicts a response value. The adjusted $\mathrm{R}^{2}$ and predicted $\mathrm{R}^{2}$ should be within approximately 0.20 of each other to be in reasonable agreement. If they are not, there may be a problem with either the data or the model. In our case, the predicted $\mathrm{R}^{2}$ of 0.897 is in reasonable agreement with the adjusted $\mathrm{R}^{2}$ of 0.9606 . The adequacy of the model was further justified through analysis of variance (ANOVA).

\subsection{Fitting of second-order polynomial equation}

An empirical relationship expressed by a secondorder polynomial equation was fitted between obtained experimental results on the basis of the BoxBehnken experimental design model and the input variables. The equation in terms of coded factors can be used to make predictions about the response for given levels of each factor. The final equation obtained in terms of coded factors is given below:

$$
\begin{aligned}
\text { COD removal }(\%)= & 62,75-5,8 \mathrm{X}_{1}+4,16 \mathrm{X}_{2}+1,09 \mathrm{X}_{3}-0,22 \mathrm{X}_{4}+0,45 \mathrm{X}_{1} \mathrm{X}_{2}+0,35 \mathrm{X}_{1} \mathrm{X}_{3}-0,45 \mathrm{X}_{1} \mathrm{X}_{3} \\
& +0,59 \mathrm{X}_{2} \mathrm{X}_{3}-0,61 \mathrm{X}_{3} \mathrm{X}_{4}-4,67 \mathrm{X}_{1}^{2}+0,46 \mathrm{X}_{2}^{2}-1,79 \mathrm{X}_{3}^{2}-3,84 \mathrm{X}_{4}^{2}
\end{aligned}
$$

\subsection{Statistical analysis}

The quality of the model was evaluated based on the coefficient of determination in addition to the
ANOVA statistical analysis. The significance of each coefficient was determined using p-value, which is used as a tool to check the significance of each 
coefficient and is necessary to understand a pattern of mutual interactions between the process variables. If the p-value is the smaller, it is the more significant significance of the corresponding coefficient and $\mathrm{P}$-values lower than 0.05 indicates that the model is statistically significant ${ }^{47}$. The regression coefficients and p-value for the second-order polynomial equation are presented in Table 5 and it could be concluded that three linear effects of $\left(\mathrm{X}_{1}, \mathrm{X}_{2}\right.$ and $\left.\mathrm{X}_{3}\right)$ and three quadratic effects of $\left(\mathrm{X}_{1}{ }^{2}, \mathrm{X}_{3}{ }^{2}\right.$ and $\left.\mathrm{X}_{4}{ }^{2}\right)$ were significant and indicate the pattern of the interactions between the variables.
The significance of the F-value depends on the number of degrees of freedom (DF) in the model. In general, the effects lower than 0.05 are significant. The ANOVA result for the COD removal shows F-value of 69.14 , which implies that the developed quadratic model has a significant effect on the response. The large value of F-value indicates that most of the variation in the response can be explained by the regression model.

Table 5. Analysis of variance (ANOVA) variables fitted to quadratic polynomial model.

\begin{tabular}{lccccccc}
\hline Source & $\mathbf{C E}$ & $\mathbf{S S}$ & $\mathbf{D F}$ & $\mathbf{M S}$ & F-value & p-value & Remarks \\
\hline Model & 62,75 & 821,27 & 14 & 58,66 & 69,14 & $<0.0001$ & significant \\
$\mathrm{X}_{1}$ & $-5,80$ & 403,10 & 1 & 403,10 & 475,11 & $<0.0001$ & \\
$\mathrm{X}_{2}$ & 4,16 & 207,33 & 1 & 207,33 & 244,37 & $<0.0001$ \\
$\mathrm{X}_{3}$ & 1,09 & 14,19 & 1 & 14,19 & 16,73 & 0,0015 \\
$\mathrm{X}_{4}$ & $-0,22$ & 0,5896 & 1 & 0,5896 & 0,6950 & 0,4208 \\
$\mathrm{X}_{1} \mathrm{X}_{2}$ & 0,45 & 0,8372 & 1 & 0,8372 & 0,9868 & 0,3401 \\
$\mathrm{X}_{1} \mathrm{X}_{3}$ & 0,35 & 0,5112 & 1 & 0,5112 & 0,6026 & 0,4526 \\
$\mathrm{X}_{1} \mathrm{X}_{4}$ & $-0,45$ & 0,8372 & 1 & 0,8372 & 0,9868 & 0,3401 \\
$\mathrm{X}_{2} \mathrm{X}_{3}$ & 0,59 & 1,39 & 1 & 1,39 & 1,64 & 0,2244 \\
$\mathrm{X}_{2} \mathrm{X}_{4}$ & $-0,21$ & 0,1892 & 1 & 0,1892 & 0,2230 & 0,6452 \\
$\mathrm{X}_{3} \mathrm{X}_{4}$ & $-0,61$ & 1,49 & 1 & 1,49 & 1,75 & 0,2100 \\
$\mathrm{X}_{1}{ }^{2}$ & $-4,67$ & 116,38 & 1 & 116,38 & 137,17 & $<0.0001$ \\
$\mathrm{X}_{2}^{2}$ & 0,46 & 1,17 & 1 & 1,17 & 1,37 & 0,2639 \\
$\mathrm{X}_{3}^{2}$ & $-1,79$ & 17,11 & 1 & 17,11 & 20,17 & 0,0007 \\
$\mathrm{X}_{4}^{2}$ & $-3,84$ & 78,44 & 1 & 78,44 & 92,45 & $<0.0001$ \\
\hline $\mathrm{CE}^{2}$ & & & &
\end{tabular}

CE: Coefficient estimate

Model adequacy checking was performed to determine whether the approximating model would give poor or misleading results. Figure 2 shows the residual and the influence plots for the experimental data obtained from this study. The predicted values obtained were quite close to the experimental values, and the points of all predicted and experimental response values fall very close to the $45^{\circ}$ line (Figure $2 a)$, indicating that the model developed was successful in capturing the correlation between the process variables on the response. Figure $2 \mathrm{~b}$ shows the standard $\%$ probability plot of residuals for a response was normally distributed, as they lie reasonably close on a straight line and shows no deviation of the variance.

3.4. Effect of variables on COD removal efficiency In order to gain a better understanding of the interaction between the independent variables and estimate the COD removal efficiency over the independent variables, three-dimensional (3D) response surface plots for the measured response were constructed from the regression equation. These representations describe the relative effects of any two variables on COD removal efficiency when the remaining variables were kept constant.

Figures $3 \mathrm{a}, 3 \mathrm{~b}$ and $3 \mathrm{c}$ show the combined effects of initial $\mathrm{pH}$ correspond with current density, electrolysis time and $\mathrm{NaCl}$ concentration, respectively. As can be seen from the figures, when initial $\mathrm{pH}$ was adjusted in the range 4-5, high removals of COD was achieved. This behaviour is by the amphoteric character of aluminium hydroxide that does not precipitate at $\mathrm{pH}$ less than 2 . In alkaline medium, a slight drop is recorded due to the consumption of the $\mathrm{OH}^{-}$ion and the formation of $\mathrm{Al}(\mathrm{OH})_{4}{ }^{-}$which is useless for water treatment ${ }^{31}$. The results are in agreement with Adhoum and Monser ${ }^{33}$ and Hanafi et al. ${ }^{32}$, who concluded that the highest COD removal efficiency has been obtained in acidic medium. 

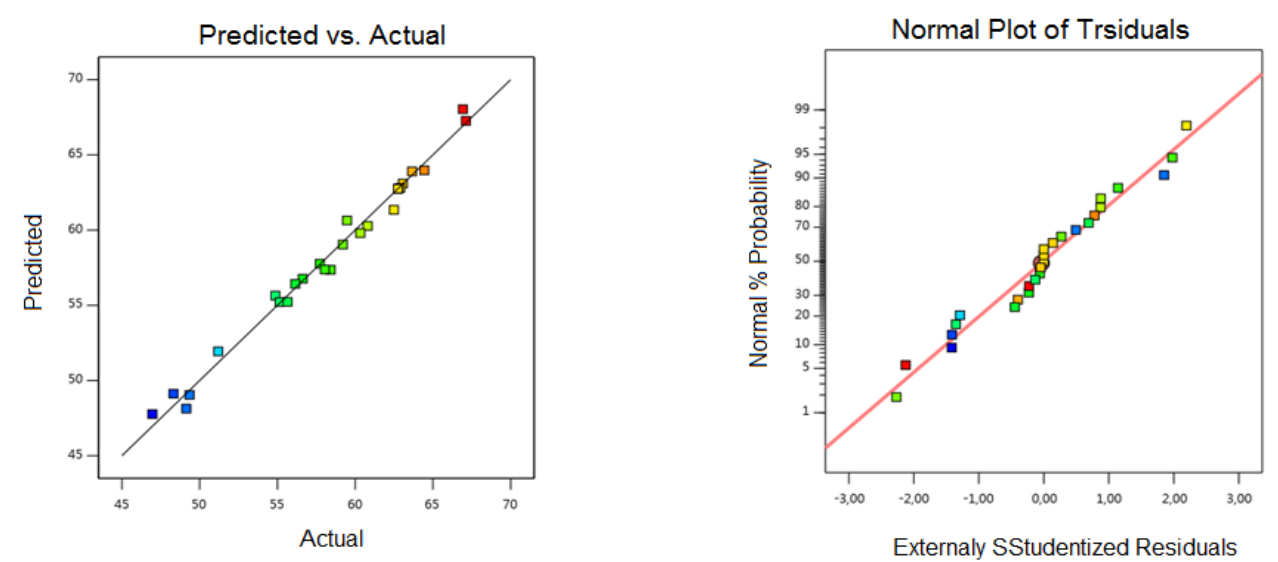

Figure 2. (a) predicted response versus actual response, (b) Normal \% probability versus residual error

This result is entirely meaningful in the application of electrocoagulation to OMW treatment since the typical $\mathrm{pH}$ of OMW is between 4.5 and 5.5 , which

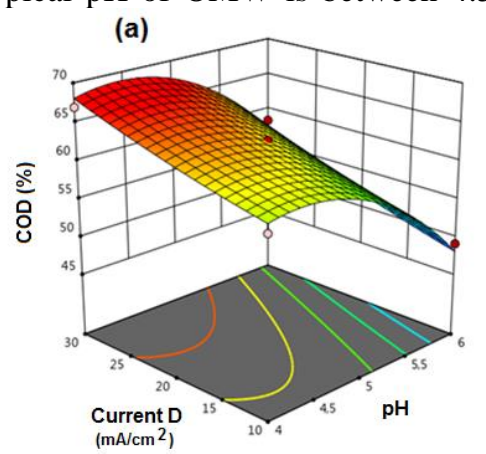

allows it to be directly treated by electrocoagulation without further $\mathrm{pH}$ adjustment.

Figure 3. Effects of (a) initial $\mathrm{pH}$ and current density (b) initial $\mathrm{pH}$ and electrolysis time (c) initial $\mathrm{pH}$ and $\mathrm{NaCl}$ concentration, on COD removal efficiency

Current density directly determines both coagulant dosage and bubble generation rates, as well as strongly influencing both solution mixing and mass transfer at the electrodes. The effects of current density correspond with initial $\mathrm{pH}$, electrolysis time and $\mathrm{NaCl}$ concentration, are presented in Figures 3a, $4 \mathrm{a}$ and $4 \mathrm{~b}$, respectively. These figures clearly show that the COD removal efficiency increase when the current density increased from 10 to $30 \mathrm{~mA} / \mathrm{cm}^{2}$. A similar observation was previously observed by Holt et al. ${ }^{48}$ and was explained by the fact that, at higher currents, $\mathrm{Al}^{3+}$ ions undergo hydrolysis, and the resulting aluminium hydroxides produce more sludge with consequent significant removal of COD. Also,

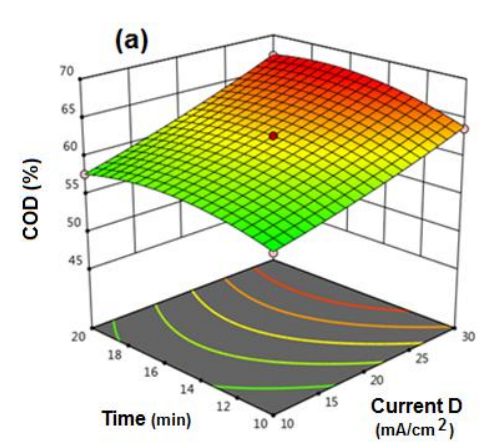

by increasing the current density of the cell, the number of hydrogen bubbles at the cathode increased, resulting in a higher upward flux and faster removal of $\mathrm{COD}^{48,49}$.

The effect of electrolysis time and initial $\mathrm{pH}$ and the effect of electrolysis time and current density as an estimate of per cent COD removal are shown in Figures $3 \mathrm{~b}$ and $4 \mathrm{a}$, respectively.

It can be depicted from the response graphs that percentage of COD removal increases slightly with increasing electrolysis time from 10 to $20 \mathrm{~min}$.

Figure 4. Effects of (a) current density and electrolysis time (b) current density and $\mathrm{NaCl}$ concentration (c) electrolysis time and $\mathrm{NaCl}$ concentration, on $\mathrm{COD}$ removal efficienc 
The surface plots for COD removal efficiency presented in Figures 3c, $4 \mathrm{~b}$ and $4 \mathrm{c}$ show the combined effects of $\mathrm{NaCl}$ concentration with initial $\mathrm{pH}$, electrolysis time and current density, respectively. The response surface of mutual interactions between the variables was found to be elliptical, and the maximum COD removal efficiency was obtained in when increasing $\mathrm{NaCl}$ concentration to $3 \mathrm{~g} \mathrm{l}^{-1}$. Similar results were reported by Moussa et al. ${ }^{50}$ and Khandegar and Saroha ${ }^{51}$. In addition to the coagulation process, when anode potential is sufficiently high, secondary reactions may also occur, such as indirect oxidation if the solution contains $\mathrm{Cl}^{-}$, the following reactions may take place in the $\mathrm{EC}$ cell $33,52,53$ :

$$
\begin{aligned}
& 2 \mathrm{Cl}^{-} \rightarrow \mathrm{Cl}_{2}+2 \mathrm{e}^{-} \\
& \mathrm{Cl}_{2}+\mathrm{H}_{2} \mathrm{O} \rightarrow \mathrm{HOCl}+\mathrm{Cl}^{-}+\mathrm{H}^{+} \\
& \mathrm{HOCl} \rightarrow \mathrm{OCl}^{-}+\mathrm{H}^{+}
\end{aligned}
$$

The formation of active chlorine species $\left(\mathrm{Cl}_{2}, \mathrm{HOCl}\right.$, $\mathrm{OCl}^{-}$) enhances the performance of the $\mathrm{EC}$ reactor through oxidation reactions.

Whereas the further increase in $\mathrm{NaCl}$ concentration decreased the COD removal efficiency. This demonstrates that an excess amount of $\mathrm{Cl}^{-}$in the solution is detrimental to the coagulation of the pollutants. Indeed, the presence of the $\mathrm{Cl}^{-}$ions in the solution containing $\mathrm{Al}(\mathrm{OH})_{3}$ forms some transitory compounds, such as $\mathrm{Al}(\mathrm{OH})_{2} \mathrm{Cl}, \mathrm{Al}(\mathrm{OH}) \mathrm{Cl}_{2}$ and $\mathrm{AlCl}_{3}$. The transitory compounds finally dissolve in the solution with excess $\mathrm{Cl}^{-}$, as a form of $\mathrm{AlCl}_{4}{ }^{-32,54}$. Thus, the amount of $\mathrm{Al}(\mathrm{OH})_{3}$ coagulants decreases, resulting in a decrease of the removal efficiency.

\subsection{Optimization and validation}

In order to determine the optimum process parameters for the maximum COD removal efficiency, Derringer's desired function methodology optimization was used in this present study. This function searches for a combination of factor levels that simultaneously satisfies the requirements for each response in the design ${ }^{36}$. According to the BBD results, the optimal operating conditions for the maximum COD removal based on Derringer's desired function methodology are found to be the initial $\mathrm{pH}$ $\left(\mathrm{X}_{1}\right)$ of 4.4 , current density $\left(\mathrm{X}_{2}\right)$ of $27.6 \mathrm{~mA} \mathrm{~cm}$, electrolysis time $\left(\mathrm{X}_{3}\right)$ of $14.1 \mathrm{~min}$, and $\mathrm{NaCl}$ concentration $\left(\mathrm{X}_{4}\right)$ of $3.2 \mathrm{~g} / \mathrm{L}$. Under these conditions, the predicted removal efficiency of COD is found to be $67.14 \%$ with a desirability value of 0.94 . This set of optimum conditions are used to validated experimentally. Triplicate experiments carried out under the optimized conditions, and the average COD removal was $67.03 \pm 0.12 \%$. The results are closely related with the data obtained from optimization analysis using desirability functions, indicating BoxBehnken design incorporate with desirability functions could be effectively used to optimize the operational parameters for the COD removal efficiency.

The efficiency of removal of COD $(67,03 \%)$ obtained under optimal operating conditions is better than those found by Inan et al. ${ }^{34}$ when they applied electrocoagulation for the treatment of OMW (52\% COD was removed by the aluminum anode) and by Hanafi et al. ${ }^{35}$ when they examined a coupled treatment process for OMW comprising electrocoagulation using an aluminum electrode and then a biological process (after electrocoagulation, the COD of OMW descended approximately $60.7 \%$ ).

\section{Conclusion}

The main objective of the present study was to investigate the efficiency of the electrocoagulation process to treat olive mill wastewater. The performance of aluminium electrodes for removal of chemical oxygen demand was modelled and optimized using response surface methodology. The effects of four important operational parameters, including initial $\mathrm{pH}$ current density, electrolysis time, and chloride concentration, were evaluated by the response surface plots. Model summary statistics showed that the developed model was adequate and precise with the experimental data. Analysis of variance showed a high coefficient of determination value $\left(\mathrm{R}^{2}\right)$ of 0.98 for ensuring a satisfactory fit of the developed second-order polynomial regression model with the experimental data. The simultaneous optimization of the multi-response system by desirability function indicated that $67.14 \%$ removal of COD can be possible by using the optimal conditions of initial $\mathrm{pH}\left(\mathrm{X}_{1}\right)$ of 4.4 , current density $\left(\mathrm{X}_{2}\right)$ of $27.6 \mathrm{~mA} / \mathrm{cm}^{2}$, electrolysis time $\left(\mathrm{X}_{3}\right)$ of $14.1 \mathrm{~min}$, and $\mathrm{NaCl}$ concentration $\left(\mathrm{X}_{4}\right)$ of $3.2 \mathrm{~g} / \mathrm{L}^{1}$. The excellent agreement between the predicted and the experimental results verified the validity of the model and the existence of an optimal point. This indicated that the RSM was a powerful tool for determining the exact optimal values of the individual factors.

\section{References}

1- P. Vossen, Growing olives for oil, In: Handbook of olive oil; Analysis and properties, Ed. by

R. Aparicio and J. Harwood; Springer publications: New York, 2013, pp. 19-56.

2- A. El-Abbassi, H. Kiai, A. Hafidi, Phenolic profile and antioxidant activities of olive mill wastewater, Food Chemistry, 2012, 132, 406-412.

3- R. Andreozzia, M. Canterinoa, I.D. Sommaa, R.L. Giudiceb, R. Marottaa, G. Pintob, A. Polliob, Effect of combined physico-chemical processes on the phytotoxicity of olive mill wastewaters, Water research, 2008, 42, 16841692.

4- S. Babic, O. Malev, M. Pflieger, A.T. Lebedev, D.M. Mazur, A. Kuzic, R. CozRakovac, 
P. Trebse, Toxicity evaluation of olive oil mill wastewater and its polar fraction using multiple whole-organism bioassays, Science of the Total Environment, 2019, 686, 903-914.

5- J.M. Ochando-Pulido, A. Martinez-Ferez, Experimental design optimization of reverse osmosis purification of pretreated olive mill wastewater, Science of the Total Environment, 2017, 587-588, 414-422.

6- J.R. Guido Greco, G. Toscana, M. Coffin,

L. Gianfreda, F. Sannino, Dephenolisation of olive mill wastewaters by olive husk, Wat. Res., 1999, 33, 3046-3050.

7- D. Bouknana, B. Hammouti, R. Salghi, S. Jodehe, A. Zarrouk, I. Warad, A. Aouniti, M. Sbaa, Physicochemical Characterization of Olive Oil Mill Wastewaters in the eastern region of Morocco, J. Mater. Environ. Sci., 2014, 5 (4), 1039-1058.

8- J.M. Ochando-Pulido, S. Pimentel-Moral, V. Verardo, A. Martinez-Ferez, A focus on advanced physico-chemical processes for olive mill wastewater treatment, Separation and Purification Technology, 2017, 179, 161-174.

9- M. Hamdi, Thermoacidic precipitation of darkly coloured polyphenols of olive mill wastewaters, Environ Technol., 1993, 14, 495-9.

10- M. Aggoun, R. Arhab, A. Cornu, J. Portelli, M. Barkat, B. Graulet, Olive mill wastewater microconstituents composition according to olive variety and extraction process, Food Chemistry, 2016, 209, 72-80.

11- C. Belaid, M. Khadraoui, S. Mseddi, M. Kallel, B. Elleuch, J.F. Fauvarque, Electrochemical treatment of olive mill wastewater: Treatment extent and effluent phenolic compounds monitoring using some uncommon analytical tools, Journal of Environmental Sciences, 2013, 25 (1), 220-230.

12- L. Davies, J. Novais, S. Martins-Dias, Influence of salts and phenolic compounds on olive mill wastewater detoxification using superabsorbent polymers, Bioresour. Technol., 2004, 95 (3), 259-268.

13- P. Paraskeva, E. Diamadopoulos, Technologies for olive mill wastewater (OMW) treatment: A review, J. Chem. Technol. Biotechnol., 2006, 81, 475-1485.

14- R. Borja, E. Sanchez, F. Raposo, B. Rincon, A.M. Jimenez, A. Martín, A study of the natural biodegradation of two-phase olive mil solid waste during its storage in an evaporation pond, Waste Manage., 2006, 26 (5), 477-486.

15- A. Roig, M.L. Cayuela, M.A. SánchezMonedero, An overview on olive mil wastes and their valorisation methods, Waste Manage., 2006, 26, 960-969.

16- C.J. McNamara, C.C. Anastasiou, V. O'Flaherty, R. Mitchell, Bioremediation of olive mill wastewater, Review, International Biodeterioration \& Biodegradation, 2008, 61, 127-134.
17- A. González-González, F. Cuadros, Effect of aerobic pretreatment on anaerobic digestion of olive mill wastewater (OMWW): An ecoefficient treatment, Food and Bioproducts Processing, 2015, 95, 339-345.

18- B. Rincón, G. Rodríguez-Gutiérrez, L. Bujalance, J. Fernández-Bolanos, R. Borja, Influence of a steam-explosion pretreatment on the methane yield and kinetics of anaerobic digestion of two-phase olive mil solid waste or alperujo, Process Safety and Environmental Protection, 2016, 102, 361-369.

19- E.S. Aktas, S. Imre, L. Ersoy, Characterization and lime treatment of olive mill wastewater, Water Res., 2001, 35, 2336-2340.

20- C.A. Santi, S. Cortes, L.P. D’Acqui, E. Sparvoli, B. Pushparaj, Reduction of organic pollutants in Olive Mill Wastewater by using different mineral substrates as adsorbents, Bioresource Technology, 2008, 99, 1945-1951.

21- P. Galiatsatou, M. Metaxas, D. Arapoglou, V. Kasselouri-Rigopoulou, Treatment of olive mill wastewater with activated carbons from agricultural by-products, Waste Manage., 2002, 22, 803-812.

22- K. Al-Malah, M.O.J. Azzam, N.I. Abu-Lail, Olive mills effluents (OME) wastewater posttreatment using activated clay, Sep. Purif. Technol., 2000, 20, 225-234.

23- J.M. Ochando-Pulido, M.D. Víctor-Ortega, A. Martínez-Ferez, Membrane fouling insight during reverse osmosis purification of pretreated olive mill wastewater, Separation and Purification Technology, 2016, 168, 177-187.

24- T. Coskun, E. Debik, N.M. Demir, Treatment of olive mill wastewater by nanofiltration and reverse osmosis membranes, Desalination, 2010, 259, 65-70.

25- M. Gotsi, N. Kalogerakis, E. Psillakis, P. Samaras, D. Mantzavinos, Electrochemical oxidation of olive oil mill wastewaters, Water Research, 2005, 39, 4177-4187.

26- U. Tezcan Un, U. Altay, A.S. Koparal, U.B. Ogutveren, Complete treatment of olive mill wastewaters by electro-oxidation, Chemical Engineering Journal, 2008, 139, 445-452.

27- N. Flores, P.L. Cabot, F. Centellas, J.A. Garrido, R.M. Rodríguez, E. Brillas, I. Sirés, 4-Hydroxyphenylacetic acid oxidation in sulfate and real olive oil mill wastewater by electrochemical advanced processes with a boron-doped diamond anode, J. Hazard. Mater., 2017, 321, 566-575.

28- E. Butler, Y.T. Hung, R.Y.L. Yeh, M.S. Al Ahmad, Electrocoagulation in Wastewater Treatment, Water, 2011, 3, 495-525.

29- J.N. Hakizimana, B. Gourich, M. Chafi, Y. Stiriba, C. Vial, P. Drogui, J. Naja, Electrocoagulation process in water treatment: A review of electrocoagulation modeling approaches, Desalination, 2017, 404, 1-21. 
30- M.Y.A. Mollah, R. Schennach, J.R. Parga, D.L. Cocke, Electrocoagulation (EC)—science and applications, Journal of Hazardous Materials, 2001, B84, 29-41.

31- H. Inan, A. Dimoglo, H. Simsek, M. Karpuzcu, Olive oil mill wastewater treatment by means of electrocoagulation, Separ. Purif. Technol., 2004, $36,23-31$.

32- F. Hanafi, O. Assobhei, M. Mountadar, Detoxification and discoloration of Moroccan olive mill wastewater by electrocoagulation, Journal of Hazardous Materials, 2010, 174, 807-812.

33- N. Adhoum, L. Monser, Decolourization and removal of phenolic compounds from olive mill wastewater by electrocoagulation, Chemical Engineering and Processing, 2004, 43, 1281-1287.

34- U. Tezcan Un, S. Ugur, A.S. Koparal, U.B. Ogutveren, Electrocoagulation of olive mill wastewaters, Separation and Purification Technology, 2006, 52, 136-141.

35- R.H. Myers, D.C. Montgomery, Response Surface Methodology: Product and Process Optimization Using Designed Experiments, 2nd Edition, John Wiley \& Sons, New York, 2002.

36- J.P. Wang, Y.Z.Chen, Y. Wang, S.J. Yuan, H.Q. $\mathrm{Yu}$, Optimization of the coagulation-flocculation process for pulp mill wastewater treatment using a combination of uniform design and response surface methodology, Water Res., 2011, 45(17), 5633-40.

37- T. Bong-yul, T. Bong-sik, K. Young-ju, P. Yong-jin, Y. Young-hun, M. Gil-ho, Optimization of color and COD removal from livestock wastewater by electrocoagulation process: Application of Box-Behnken design (BBD), Journal of Industrial and Engineering Chemistry, 2015, 28, 307-315.

38- A. Talebi, I. Norlil, A.F.M. Alkarkhi, T.T. Teng, Optimization of Coagulation Process for Landfill Leachate Pre-Treatment Using Response Surface Methodology (RSM), Journal of Sustainable Development, 2009, 2 (2), 159-167.

39- American Public Health Association (APHA), Standard Methods for the Examination of Water and Wastewater, 19th ed., APHA, AWWA, WPCF, Washington, DC, 1995.

40- P.H. Holt, G.W. Barton, M. Wark, A.A. Mitchell, A quantitative comparison between chemical dosing and electrocoagulation, Colloids Surf. A: Physicochem. Eng. Aspects, 2002, 211, 233-248.

41- M.M. Emamjomeh, M. Sivakumar, Review of Pollutants Removed by Electrocoagulation and
Electrocoagulation/Flotation Processes, Journal of Environmental Management, 2009, 90, 1663-1679.

42- H.A. Moreno-Casillas, D.L. Cocke, J.A.G. Gomesa, P. Morkovsky, J.R. Parga, E. Peterson, Electrocoagulation mechanism for COD removal, Separation and Purification Technology, 2007, 56, 204-211.

43- G.H. Chen, Electrochemical technologies in wastewater treatment, Sep. Purif. Technol., 2004, 38, 11-41.

44- M. Rebhun, M. Lurie, Control of Organic Coagulation and Floc Separation, Water Science and Technology, 1993, 27(11), 1-20.

45- J. Prakash Maran, S. Manikandan, Response surface modeling and optimization of process parameters for aqueous extraction of pigments from prickly pear (opuntia ficus-indica) fruit, Dyes and Pigments, 2012, 95, 465-472.

46- C. M. Liyana-Pathirana, F. Shahidi, Optimization of extraction of phenolic compounds from wheat using response surface methodology, Food Chemistry, 2005, 93, 47-56.

47- J. Segurola, N. S. Allen, M. Edge, A. M. Mahon, Design of eutectic photoinitiator blends for UV/visible curable acrylated printing inks and coatings, Progress in Organic Coatings, 1999, 37, 23-37.

48- P.K. Holt, G.W. Barton, C.A. Mitchell, The future for electrocoagulation as a localised water treatment technology, Chemosphere, 2005, 59, 355-367.

49- J. Duan, J. Gregory, Coagulation by Hydrolysing Metal Salts, Advances in Colloid and Interface Science, 2003, 100-102, 475-502.

50- D.T. Moussa, M.H. El-Naas, M. Nasser, M.J. Al-Marri, A comprehensive review of electrocoagulation for water treatment: Potentials and challenges, review, Journal of Environmental Management, 2017, 186, 24-41.

51- V. Khandegar, A.K. Saroha, Electrocoagulation for the treatment of textile industry effluent - a review, J. Environ. Manag., 2013, 128, 949-963.

52- S. Gao, M. Du, J. Tian, J. Yang, J. Yang, F. Ma, J. Nan, Effects of Chloride Ions on Electrocoagulation-Flotation Process with Aluminum Electrodes for Algae Removal, Journal of Hazardous Materials, 2010, 182 (1-3), 827-834.

53- M. Zaied, N. Bellakhala, Electrocoagulation treatment of black liquor from paper industry, J. Hazard. Mater., 2009, 163, 995-1000.

54- C.T. Wang, W.L. Chou, Y.M. Kuo, Removal of COD from laundry wastewater by electrocoagulation / electroflotation, J. Hazard. Mater., 2009, 164, 81-86. 